\title{
REFLEXE SRPNOVÝCH UDÁLOSTÍ ROKU 1968 V TISKU
}

\author{
JAROSLAV SOMMER - VOJTĚCH JEDLIČKA
}

SOMMER, Jaroslav - JEDLIČKA, Vojtěch: Reflection of the August 1968 Events in the Press, 2019, Vol. 1, Issue 1, pp. 127 - 135. DOI: 10.17846/CEV.2019.01.1.127-135.

\begin{abstract}
The article deals with how the Warsaw Pact invasion of Czechoslovakia in August 1968 and the following events have been reflected in the news. The authors analyse texts from selected important Czechoslovak, Soviet and also later Czech and Russian newspapers in 1968 and also after each ten year anniversary of the Soviet invasion. The authors point out the changes in both characterization and evaluation of the events of August 1968 throughout the decades. The article emphasises the changes that have occurred in Russian press from the 1990s to the current era.
\end{abstract}

KEYWORDS: August 1968. Czechoslovakia. Soviet Union. Press.

Ve studii se zabýváme reflexí vpádu vojsk Varšavské smlouvy do Československa v srpnu roku 1968 v tisku. Jako zdroj posloužily texty publikované ve vybraných československých, sovětských, českých a ruských periodikách. Analýza denního tisku poskytla materiál, jenž dokládá proměny ve vnímání a interpretaci nejen samotných událostí poslední třetiny srpna roku 1968, ale též odráží širší společensko-politický kontext samotné invaze, tak i období, ve kterém byly jednotlivé texty vydány. Při studiu novinových článků jsme se vzhledem k rozsahu tohoto článku zaměřili na texty otištěné v druhé polovině srpna roku 1968 a pak vždy v několika dnech před a po desetiletých výročích vpádu vojsk do Československa, tedy v roce 1978, 1988, 1998, 2008 a 2018. Pochopitelně tak nezachycujeme přesně ta zlomová výročí v dějinách ČSSR i SSSR a nástupnických států, kdy by bylo možné zaznamenat výrazné proměny v reflexi vpádu vojsk do Československa $\mathrm{z}$ roku na rok. Stejně tak jsme si vědomi toho, že při tomto vymezení se nelze věnovat všem nuancích, které by bylo možné sledovat při analýze všech padesáti výročí např. v souvislosti se zaváděním glasnosti v Gorbačovově ére. Přesto lze konstatovat, že články nepostrádají svou výpovědní hodnotu i při takto zúženém pohledu.

Analýze jsou podrobeny články publikované $\mathrm{v}$ denících vydávaných stranickými orgány a v některých dalších významných periodikách. Z československého tisku tak byly vybrány Rudé právo (později přejmenováno na Právo) a Mladá fronta (později Mladá fronta DNES), ze sovětského a následně ruského tisku Pravda (Правда), Komsomolskaja Pravda (Комсомольская Правда), Izvěstija (Известия), Novaja gazeta (Новая газета) а Večerňaja Moskva (Вечерняя Москва).

\section{ROK 1968: ČESKOSLOVENSKÝ TISK}

Zkoumat bezprostřední reflexi vpádu vojsk v roce 1968 v československém oficiálním tisku je prakticky nemožné, jelikož činnost redakcí námi zkoumaných periodik byla krátce po vpádu vojsk zastavena (v některých př́padech násilně) a obnovena byla až v prvních zářijových dnech.

Poslední oficiální vydání Rudého práva před invazí nese datum 21. srpna 1968 a číslo 231, články týkající se politiky a ekonomiky jsou psány v duchu „polednové“ politiky a akčního programu. Další řádné vydání Rudého práva bylo publikováno až 3. září 1968 pod číslem 243. Některé (oblastní) redakce však publikovaly v takto vzniklém mezidobí.

Jako př́klad uved’me redakci ostravskou, která nezávisle na pražské vydávala několikrát denně, pod hlavičkou „Spojené redakce (deníky)“, aktualizovaná vydání informující občany o dění ve státě. Tato vydání jsou laděna protiokupačně: vstup vojsk je označován jako okupace, invaze, 
zrada apod. V novinách tak nalézáme titulky: Násilná okupace ČSSR; Opustte naši zemi; To jste bratři? (Spojené deníky 1968a-c) a mnoho dalších.

Po oficiálním obnovení činnosti redakcí Rudého práva se hlavním tématem stává snaha o „normalizaci situace“ - tedy volání po obnovení normálního života v zemi a plnění předpokladů pro odchod sovětských vojsk, jak je patrné i z titulků článků Rudého práva (Rudé právo 1968a-c).

\section{ROK 1968: SOVĚTSKÝ TISK}

Hned 21. srpna 1968 sovětská Pravda informuje prostřednictvím úvodníku ЗАЯВЛЕНИЕ TACC o tom, že „straničtí a státní predstavitelé Československé socialistické republiky se obrátily k Sovětskému svazu a druhým státům s prosbou o neodkladnou pomoc bratrskému československému národu, včetně vojenských sil“ proti kontrarevolučním silám ve spojení s vnějšími nepřátelskými silami (Pravda 1968a).

Od této chvíle se stává „bratrská pomoc Československu“ hlavním tématem všech námi studovaných periodik na několik dalších dní. Deníky Pravda, Izvěstija i Večerňaja Moskva poskytují jednotný výklad událostí, v textech je vstup vojsk do ČSSR označován jako „bratrská pomoc“. Pravděpodobným záměrem celé této propagandistické akce je vzbudit v čtenáři dojem, že Sovětský svaz (spolu s ostatními účastnícími se státy) je zachráncem, který jde znovu na pomoc Československu (v mnoha článcích bývá uveden odkaz na osvobození republiky v roce 1945, např. v článku На помощь братьям (Borzenko 1968)). Velmi často skloňovanou frází v titulcích se stává „internacionální, bratrský závazek“ (Korrespondenty Pravdy i TASS 1968, Pravda 1968b).

\section{ROK 1978}

Připomínku toho, že před deseti lety došlo $\mathrm{k}$ vstupu vojsk Varšavské smlouvy na území Československa, nalezneme již $\mathrm{v}$ úvodníku Rudého práva s názvem $V$ zájmu socialismu, $v$ zájmu našeho lidu (Rudé právo 1978a). Cílem tohoto úvodníku však není vzpomenout konkrétní události oněch dní ani např. jména státních (resp. stranických) činitelů té doby.

Samotný akt invaze je zmíněn až v druhém odstavci a nazván jako „internacionální bratrská pomoc“ (Rudé právo 1978a), kromě jeho pojmenování již není nijak dále komentován a připomínán. Zbylý obsah rozsáhlého textu pak poukazuje na velmi zdařilý vývoj státu za posledních deset let, především vyzdvihuje pozitivní vliv přátelství se Sovětským svazem na vývoj ČSSR.

Sovětská a československá reflexe v denním tisku je v roce $1978 \mathrm{v}$ podstatě totožná. Spolupráce redakcí a záměr o zprostředkování stejného oficiálního názoru jsou zřejmé z toho faktu, že námi zkoumané deníky si mezi sebou články předávaly a publikovaly je bud' přímo v doslovném překladu, formou výtahu, nebo na ně reagovaly a poukazovaly.

V sovětské Pravdě tak nalézáme článek Во имя победы социализма (Pravda 1978), který je převyprávěním výše zmíněného úvodníku. Samo Rudé právo o tomto „přetisku“ informuje o dva dny později v článku Pevná tř́iní pouta (Rudé právo 1978b).

Podobný př́stup pozorujeme i u článku Aloise Indry Верность интернационализму (Indra 1978a), jenž byl otištěn 21. srpna v deníku Izvěstija a o dva dny později v Rudém právu v českém znění (Indra 1978b). Indra v tomto článku také nezmiňuje konkrétní události srpna 1968. Jeho záměrem je především vyvracet argumenty „protisocialistických a imperialistických“ sil (jak na Západě, tak v ČSSR), které interpretují „bratrskou pomoc“ v rozporu s oficiálním stanoviskem KSČ, a to opět s důrazem na klady vývoje státu a společnosti po roce 1968 (resp. po dubnu 1969, kdy bylo definitivně vyměněno vedení KSČ a jejím prvním tajemníkem byl zvolen Gustáv Husák) (Indra 1978b). 
Další články jsou psané též jako reakce na imperialistické snahy o dezinterpretaci událostí před deseti lety s cílem využít „československé téma“ v boji proti bloku socialistických států jako celku.

První o těchto „snahách“ informuje československou veřejnost Rudé právo článkem List Pravda k protičeskoslovenské kampani uměle rozdmýchávané na Západě (Rudé právo 1978b), který je parafrází článku J. Birjukova Chtějí ohrozit uvolňování, publikovaným 19. srpna v Pravdě (Rudé právo 1978b). Reakce na Birjukovův článek je umístěna i na úvodní stránce Mladé fronty z 21. srpna (Mladá fronta 1978).

Jako důkaz, že i v zemích Západu se vyskytují prosovětské názory, vydává Rudé právo dne 23. srpna Historické vítězství socialismu: Bratrské listy k událostem pred 10 lety (Rudé právo 1978c). Jedná se však jen o otištění krátkých úryvků z „bratrských listů“ (periodik komunistických stran Lucemburska, USA a Portugalska), ve kterých je oslavováno zmíněné vítězství socialismu a zlepšení společenské a ekonomické situace ČSSR za posledních deset let.

Zajímavým př́kladem „manipulace s informacemi“ (resp. jejich vytržením z kontextu a následném využití pro vlastní účely) je otištění úryvků z úvodníku anglického večerníku Evening Standard v článku nesoucím název Hlas pokrytectví o Západu (Rudé právo 1978d). Úvodník dle Rudého práva odsuzuje "pokrytecké vzpomínání většiny britských listư“ (ibid.) na srpnové události. Rudé právo z článku cituje fráze jako „zmatená Dubčekova vláda“, „(nyní) ... je v zemi klid“, „Dubčekưv expriment s, demokratickým socialismem “ (ibid.) a pokládá je za vystihující. Stejně tak si z onoho úvodníku propůjčuje tvrzení, že „... je žádoucí, aby pokračoval určitý vliv Sovětského svazu v Československu. " (ibid.). Čteme-li ale úryvky z anglického večerníku nezaujatě, zjištujeme, že se rozhodně nejedná o uznání adekvátnosti sovětského řešení v roce 1968. Text pouze nabízí trochu jiný úhel pohledu na polednovou politiku a okupaci jako její následek, než byl zřejmě nabízen ostatními periodiky. Mimo jiné je zde obsažen ten názor, že rozhodnutí nezasáhnout bylo od organizace NATO v srpnu 1968 správné, v opačném př́ípadě by totiž mohlo dojít k daleko většímu mezinárodnímu konfliktu než k proběhnuvší invazi (ibid.).

\section{ROK 1988: ČESKOSLOVENSKÝ TISK}

Rudé právo se o dvacetiletém výročí zmiňuje primárně jen ve dvou článcích (další články, týkající se výročí, jsou bud’ přetiskem článků z jiných periodik sovětských i československých, či stručnou reakcí na ně).

V prvním př́padě se jedná o rozsáhlý text s názvem Obrana socialismu - nedělitelný úkol strany a lidu (Rudé právo 1988a). Teprve po několika odstavcích se ukazuje, že by se mělo jednat o článek zaměřený na problematiku invaze a pražského jara. Až od odstavce Zrada polednové politiky autor zprostředkovává aktuální výklad polednového období, pražského jara a internacionální pomoci v roce 1968, v závěru textu se tomuto tématu už ale opět nevěnuje a hovoří o cílech (resp. vizích) strany a státu do budoucna (zejména ve smyslu plánované přestavby). Cílem článku je předat čtenáři názor, že situace nepříznivá pro ČSSR v roce 1968 byla důsledkem několika okolností: nedostatečnou vizí a programem KSČ, nevhodným vedením KSČ v čele s nerozhodným Dubčekem a rozvojem pravicových sil ve společnosti (ibid.).

Druhý článek, vztahující se k výročí invaze, je publikován o tři dny později. Nese název Rušivé akce v Praze (Rudé právo 1988b) a stručně informuje o „skupinách osob, [které] se pokoušely [v sobotu a neděli 20. a 21. 8. 1988] o rušivé akce na Václavském náměstí u sochy svatého Václava [... kdy] za účasti cizích státních příslušníkư televizní a rozhlasové štáby a dalši žurnalisté ze západních sdělovacích prostředků usilovně vyhledávali senzace " (ibid.). Že se skutečně jednalo o demonstrace ke dvacetiletému výročí okupace, které se účastnilo až deset tisíc lidí (Hertl 2018), není 
Jaroslav Sommer - Vojtěch Jedlička

v článku vůbec zmíněno. Podobným způsobem o téže akci informuje i Mladá fronta pod titulkem K rušivým akcím v Praze (Mladá fronta 1988).

\section{ROK 1988: SOVĚTSKÝ TISK}

Oficiální sovětskou reflexi nám v roce 1988 přináší ještě užší množství článků, než tomu bylo při výročí desetiletém v roce 1978.

Podle článku Rudého práva $V$ zájmu pracujících: Sovětský list Pravda cituje z článku RP o 20. výroči poskytnutí internacionální pomoci (Rudé právo 1988c) se v Pravdě vyskytuje výtah z výše zmíněného článku Obrana socialismu - nedělitelný úkol strany a lidu (Rudé právo 1988a). Jedná se však o jediný článek v Pravdě, který se o událostech v Československu v roce 1968 zmiňuje.

Izvěstija nabízejí svým čtenářům také pouze jeden článek, který o dvacetiletém výročí informuje (obdobně jako v roce 1978) zase jen nepř́mo. Jedná se o reakci Alexandra Kondrašova na „protičeskoslovenskou kampaň na Západě“ (Kondrašov 1988). Již v prvních částech textu se nepíše o jubileu pomoci Československu, ale jubileu "propagandistické kampaně Západu“ (ibid.). Je však nutné podotknout, že zmíněné kampani autor článku věnuje jen úvodní část textu, ve zbylé části pak dochází k obhajobě sovětského postupu v roce 1968. A právě způsob autorovy argumentace je důkazem drobné změny v reflexi srpnových událostí. Kondrašov uvádí, že v západním tisku je vstup vojsk do ČSSR označován „zastrašujícími“ termíny „вторжение“, „оккупация“ a „подавление“ (ibid.). V celém jeho článku však nenacházíme, na rozdíl od textů z roku 1978, tradiční sovětské označení „братская помощь“ ani jednou.

Text je psán již v době tzv. glasnosti a její vliv na článek je patrný. Sám autor uznává, že v dnešní době (srpen 1988) je velká část událostí historie SSSR přehodnocována. Vpád vojsk varšavské smlouvy do ČSSR však Kondrašov mezi tyto události neřadí. Přesto v článku nabízí čtenářum některé myšlenky, které argumentují proti nutnosti vstupu vojsk, ačkoliv je následně vyvrací.

Přestože Kondrašov existenci antisocialistických sil v ČSSR v roce 1968 a zájem Západu o vytržení ČSSR z Východního bloku na jednom místě článku potvrzuje, připouští i fakt, že v Československu mohl skutečně probíhat jen proces „demokratizace“. Pomocí různých argumentů se však snaží poukázat na nesmyslnost takového faktu (ibid.).

Kondrašov též uvádí, že Západ obviňuje SSSR ze stylu řešení mezinárodních problémů, konkrétně upřednostňování vojenských řešení. Jako protiargument poukazuje na snahu diplomatického řešení situace pomocí dvou a vícestranných setkání v Drážd’anech, Varšavě, Bratislavě a dalších, které však řešení nepřinesly. Stabilizace situace pomocí vstupu vojsk tak byla, dle Kondrašova, nevyhnutelná (ibid.).

Další zmínku o „jubileu“ nacházíme v periodiku Večerňaja Moskva. Ta dne 22. srpna 1988 informuje o uskutečnění a nuceném ukončení vzpomínkové akce, jež proběhla 21. srpna 1988 na Puškinově náměstí (Trajnin 1988). Podle autora textu se na náměstí sešlo několik lidí, kteří začali vykřikovat „provokativní hesla“, rozdávali „pomlouvačné letáky“ a dalšími způsoby narušovali veřejný pořádek (ibid.). Jelikož se účastníci akce odmítli podř́ídit požadavkům milice, musela být akce ukončena (ibid.). Prakticky stejné informace (i pod podobným názvem) předává týž den Rudé právo československým čtenářům (Rudé právo 1988c).

\section{ROK 1998}

Rok 1998 je prvním desetiletým výročím, kdy jak v České republice, tak v Ruské federaci je možné publikovat bez předchozí ideologické zátěže. Reflexe srpnových událostí roku $1968 \mathrm{v}$ tisku se tak v obou případech značně liší od výročí předchozích. Pro označení vpádu vojsk se již neužívají 
termíny „bratrská, internacionální pomoc“, nýbrž „invaze“, „okupace“ a v tomto duchu jsou psány i samotné články.

V českém tisku se tak ve většině denních periodik stávají události srpna 1968 hlavním tématem po dobu několika dní. Námi studovaná Mladá fronta Dnes (MF Dnes) k této př́ležitosti i vydává zvláštní př́lohu. Cílem většiny textů MF Dnes z této doby je nejen připomenout konkrétní okolnosti a průběh srpnové okupace, ale především nabídnout čtenáři stanoviska autorů článků - často též významných osobností té doby.

K zprostředkování reflexe pomocí výše zmíněného „připomenuti“ " postačí uvést dva z mnoha titulků: Poznal, jaké to je hledět do hlavně samopalu (Baroch 1998); Srpen 1968: stovka mrtvých, stovky zraněných, miliardové škody (Pacner 1998).

Z článků spíše úvahového charakteru přinášejících stanoviska uved’me jako příklad text M. C. Putny, ve kterém pohlíží na srpen 1968 v celosvětovém kontextu „sladkých šedesátých“ jako na jejich přirozenou součást a vlastně i na jeden z jejich nezbytných následků (Putna 1998).

J. Dienstbier pak ve svém článku poukazuje na fakt, že Češi mají tendenci vzpomínat na rok 1968 (nejen) jako na „porážku“ (Dienstbier 1998). Místo srpna 1968 by tak dle autora mělo být více vyzdvihováno pražské jaro a proces demokratizace společnosti, jež nebyla způsobena úzkým kruhem těch či oněch komunistů, ale samotnými občany, kteří tak mají právo být na sebe hrdí. (ibid.).

Reflexe zprostředkovaná ruským tiskem v roce 1998 má výjimečný charakter (v porovnání s předchozími i následujícími výročími). Izvěstija i Večerňaja Moskva (námi studovaná Pravda ukončila činnost v roce 1991) věnují třicetiletému výročí invaze poměrně velký mediální prostor.

Periodika se tématu okupace věnují již s předstihem a obě se o výročí invaze zmiňují hned na titulní straně. Izvěstija tak publikují vyjádření osmi osob, kterých se vstup vojsk do ČSSR nějakým způsobem přímo týkal (Šikarev 1998). Konkrétně se jedná o B. Šimona a Č. Císaře (oba představitelé reformního křídla KSČ v roce 1968), L. Vaculíka, J. Kavana, K. Katuševa (bývalý člen ÚV KSSS), A. Jakovleva (reprezentant ÚV KSSS v Praze v době invaze), A. Majorova (sovětský generál vyjadřující lítost nad svou účastí při invazi) a L. Bogorazové (účastnice „Demonstrace sedmi“ na Rudém náměstí 25. srpna 1968) (ibid.).

V článku je vyjádřeno mnoho rozdílných názorů a úhlů pohledu na srpnové události roku 1968, v naprosté většině ale invazi odsuzujících. Tato skutečnost je do značné míry vyjádřena již v perexu: „Против маленького невоинственного государства в иентре Европь были брошены полмиллиона солдат и семь тысяч танков - больше, чем под Сталинградом в 1943 году. Чехи и словаки не сопротивлялись, они с достоинством перенесли унижение. И одержали величайшую из возможных побед - победу духа“" (ibid.).

Izvěstija se výročí věnují ještě 22. srpna 1998 publikováním vzpomínek Vladlena Krivošejeva, korespondenta deníku Izvěstija, jenž od roku 1965 do prvních dnů invaze v roce 1968 působil v Praze. Krivošejev uvádí myšlenky, které v předchozích výročích vstupu vojsk do ČSSR neměly možnost být publikovány, tedy že vstup vojsk států Varšavské smlouvy rozhodně nebyl nutný z důvodu potlačení kontrarevoluce, jež bud' vůbec neexistovala, nebo nebyla natolik silná a dobře organizovaná, aby proti ní musela zasáhnout tak obrovská vojenská síla. Jako pravé důvody Krivošejev uvádí záměr „zastrašit“ občany ČSSR, ukázat sílu Sovětského svazu a bloku socialistických států jako celku a dostat do ČSSR armádu SSSR kvůli ochraně hranic bloku (Krivošejev 1998).

V článku nalézáme ještě jeden důležitý moment. Krivošejev vzpomíná na setkání s Dubčekem a dalšími představiteli státu, které proběhlo 17. srpna 1968, tedy pouhé tři dny před začátkem invaze. Podle Krivošejeva bylo na Dubčekovi a ministru národní obrany Dzúrovi patrné, že již v ten den museli vědět o nadcházející invazi (ibid.). Právě spory o tom, zda vedení státu a KSČ vědělo o uskutečnění invaze před jejím zahájení, existují dodnes. 
Večerňaja Moskva v roce 1998 věnuje tématu invaze rovněž mnoho prostoru, pro ilustraci charakteru reflexe uved’me alespoň titulek z 15. srpna: Что аукнулось в 1968-м [...] (К 30-летию чехословацкой трагедии) (Kobylkina 1998).

\section{ROK 2008}

V roce 2008 se způsob reflexe v českém tisku o moc neliší od toho před deseti lety, články v periodikách jsou více zaměřeny na dobová svědectví, vzpomínky pamětníků a známých osobností z různých odvětví veřejného života.

Vedle těchto textů periodika samozřejmě uvádějí i články spíše úvahového charakteru. Konkrétně v MF Dnes z 16. srpna můžeme najít celý „názorový speciál“. Z jeho obsahu vyzdvihněme (vzhledem k pozorování změn reflexe) článek Pavla Kosatíka Katastrofa osmašedesátého roku ještě neskončila (Kosatík 2008). Hlavním cílem článku je vyvrátit „klišé, [...] že šlo o boj chytrých komunistů s hloupými, jemuž nestranická většina veřejnosti bezmocně přihližela - až do trpkého konce“ (ibid.). Kosatík poukazuje na fakt, že srpen 1968 (a jemu předcházející pražské jaro) bylo dílem především občanů, široké veřejnosti, které byla dána možnost se projevit (díky výměně vedení KSČ a jeho aktivitě až do srpna 1968). Tedy jak napovídá titulek, Kosatík se snaží mnoha argumenty demonstrovat fakt, že pozůstatky srpna 1968 si každý, kdo jej zažil, nese stále v sobě. Řadí tak rok 1968 k ostatním osudovým ranám pro český národ (1938 a 1948) (ibid.).

Kromě nespočtu článků odsuzujících invazi najdeme i prezentaci názoru opačného, tedy prosovětského, a to prostřednictvím rozhovoru se sovětským generálem Pavlem D. Kosenkem (Pazderka 2008). Kosenko v něm prezentuje názor, že v Československu v roce 1968 skutečně existovaly kontrarevoluční síly a že včasný zásah vojsk Varšavské smlouvy zabránil vypuknutí třetí světové války (ibid.).

Daleko překvapivější je však reflexe v tisku ruském: o čtyřicetiletém výročí invaze vojsk do ČSSR se v roce 2008 nepíše v námi studovaných periodikách vůbec. Izvěstija a Večerňaja Moskva nenabízejí ani jednu krátkou poznámku o vpádu vojsk. Tato skutečnost je velmi zajímavá vzhledem $\mathrm{k}$ tomu, jak důležitým se „československé téma“ stalo v ty samé dny před deseti lety. $\mathrm{Z}$ hlediska sledování změn reflexe $\mathrm{v}$ tisku v průběhu padesáti let však i ignorování studovaného tématu lze označit za reflexi (byt' „nulovou“).

\section{ROK 2018: RUSKÁ REFLEXE}

V roce 2018 se Izvěstija již tématu invaze vojsk do ČSSR věnují, byt jen prostřednictvím jednoho článku. Jedná se o „názor“ A. Vedrussova s titulkem Вспомнить всё. Zatímco v roce 1998 došlo v Izvěstijích k „odsouzení “ invaze, tento článek sovětský postup v roce 1968 do jisté míry obhajuje („[...] как бы они [чехи] поступили на нашем месте [?], Был ли у СССР другой вариант?“) a uvádí argumenty, proč by dnes Rusové neměli být „souzeni (jinými, ale ani sami sebou)“ za vstup vojsk do ČSSR (Vedrussov 2018). Uved’me jen některé z nich.

Autor uvádí, že vstup vojsk byl vyvolán přímou prosbou Československa. Nezmiňuje však známý „Zvací dopis“, ale telefonát Dubčeka L. Brežněvovi, jenž měl proběhnout 16. srpna 1968 (ibid.). Dodnes se však vedou spory, zda tento telefonát vůbec proběhl, zatím nebyl uveden žádný př́mý důkaz o uskutečnění takového telefonátu.

Vedrussov dále upozorňuje na existenci „protiruských“ nálad a postojů české společnosti. Podle něj Češi nepřistupují objektivně v hodnocení vlastní historie: Rusům (a tehdejšímu SSSR) jsou Češi dnes schopni vyčítat jakékoliv „reálné i domnělé chyby“, zatímco zemím Západu dnes nevytýkáme prakticky nic (včetně Mnichovské dohody). Podle autora je to však způsobeno současným "globálním trendem“ (ibid.). 
Zatímco v roce 1998 byl v Izvěstijích čtenáři předložen názor, že zájem Západu o ČSSR a kontrarevoluce nemusely být jedinými důvody ke vstupu vojsk, Vedrussov označuje samo pražské jaro jako „první ,barevný prevrat“", tedy „nástroj [...] sloužící cílưm expanzivní politiky USA“ (ibid.).

Články na téma výročí invaze nalézáme i v dalších denících, reflexe událostí se v nich různí. Určitou obhajobu sovětského postupu nalézáme také v článku Komsomolské pravdy (Grišin 2018).

Jiná (takřka opačná) stanoviska prezentuje např́íklad Novaja gazeta, která ve svém článku k výročí označuje vpád vojsk Varšavské smlouvy do ČSSR jako „гвоздь в гроб мирового коммунизма“. Charakter reflexe prezentují úryvky: „Танки в Праге - таким был ответ руководства СССР на перестройку и гласность в Чехословакии, которые назывались [...] - Пражская весна [...] Конечная иель формулировалась в несльханных (для нас) словах: ,Соииализм с человеческим тииом“" (Bajmuchametov 2018).

Jedním z článků deníku Rossijskaja gazeta je rozhovor se třemi českými historiky: J. Němečkem, E. Voráčkem a J. Rychlíkem na téma čtyř „osmičkových“ mezníkủ československé historie: 1918, 1938, 1948, 1968; největší prostor je věnován poslednímu (Sněgirev - Fronin, 2018). Prostř̌ednictvím rozhovoru se tak může čtenář setkat $s$ aktuálním českým pohledem na problematiku. V textu nalézáme tato označení pro vpád vojsk: „дискредитация идеи социализма“ (ibid.). Do diskuse o postoji Čechů a Slováků $\mathrm{k}$ Rusům přidává Němeček tvrzení, že v Československu do invaze převažovaly (na rozdíl od Polska) postoje rusofilní a že kladný vztah k Rusům může být obnoven až v té chvíli, kdy Rusové pochopí, že události srpna 1968 se staly pro Čechy tragickou "ranou, která se bude hojit ještě hodně dlouho“ (ibid.).

\section{ROK 2018: ČESKÁ REFLEXE}

Reflexe událostí v českém tisku je v roce 2018 velmi rozsáhlá, obdobně jako v letech 2008 a 1998 je výročí invaze hlavním tématem naprosté většiny periodik (nejen denních), noviny i časopisy vydávají speciální přílohy, zvláštní vydání. Čtenáři je tak nabízeno obrovské množství různých textů mnoha forem, které ho mohou informovat a poskytnout náměty k zamyšlení a tvorbě vlastního názoru na celou problematiku.

V porovnání s předchozími porevolučními výročími je charakter reflexe událostí o něco rozmanitější. Větší časový odstup od srpna 1968 (a od dalších mezníků vývoje státu) dovoluje autorům hledět na okupaci a další události $\mathrm{z}$ více úhlů pohledu. Nicméně základní charakter reflexe se nemění, vstup vojsk Varšavské smlouvy do ČSSR je stále vysvětlován jako invaze, okupace, zásah proti státní suverenitě.

Poměrově také nalézáme více článků bud’ poukazujících na souvislosti mezi událostmi roku 1968 a dnešní politickou situací (zejména pak vztahu Ruska a České republiky), nebo využitím tématu „1968“ k poukázání na současné problémy dnešní společnosti a politické scény, např. články Když prezident 21. srpna mlčí (Zídek 2018), Místo piety protest proti Babišovi (Martinek 2018).

\section{ZÁVĚR}

Autoři poukazují na společné rysy a rozdíly v charakterizaci událostí, které provázely vpád vojsk do Československa. V letech 1978 a 1988 je nápadné zvláště přejímání jednotlivých textů mezi československým a sovětským tiskem. Od 30. výročí vpádu v roce 1998 pak lze pozorovat především rozdílnost v prezentovaném pohledu na srpnové události. Zatímco česká reflexe je v letech 1998, 2008 a 2018 v podstatě neměnná, ruská se paradoxně čím dál více přibližuje ideologicky zatížené rétorice používané $\mathrm{v}$ dřívějším sovětském tisku. $\mathrm{V}$ článku je tak zdůrazněn posun, $\mathrm{k}$ němuž došlo na stránkách ruského tisku od 90. let do současnosti. 
Jaroslav Sommer - Vojtěch Jedlička

\section{SUMMARY}

In the article the authors focus on the reflection of the Warsaw Pact invasion of Czechoslovakia in the press in each ten year anniversary following the events of August 1968, i. e. in 1978, 1988, 1998, 2008 and 2018. The subject of analysis are the articles published in the Czechoslovak newspapers Rudé právo (later renamed as Právo) and Mladá fronta (later renamed Mladá fronta $D N E S$ ). From the Soviet and subsequently Russian press, the articles for the research were chosen from the newspapers Pravda, Komsomolskaja Pravda, Izvěstija, Novaja gazeta and Večerňaja Moskva. Attention was first paid to the contents of the selected press in the year 1968 and then the authors deal with the reflection of these events during the individual anniversaries, pointing out the common features and differences in the characterization of the events that accompanied the Warsaw Pact invasion of Czechoslovakia. In 1978 and 1988 the taking over of individual texts between the Czechoslovak and Soviet press is especially noticeable. From the 30th anniversary of the invasion in 1998 one can observe the differences in the presented view of the events of August 1968. While the Czech reflection in 1998, 2008 and 2018 are essentially unchanging, the Russian reflection is paradoxically more and more similar to the ideologically charged rhetoric of the former Soviet press.

\section{LITERATURA}

Bajmuchametov, Sergej, 2018. Skoro oseň, na ulicach tanki. In: Novaja gazeta 2018/90, 18 - 19. Baroch, Pavel, 1998. Poznal, jaké to je hledět do hlavně samopalu. In: Mladá fronta DNES 9/195, 1. Borzenko, S., 1968. Na pomošč bratjam. In: Pravda 1968/235, 4.

Další kroky k normalizaci. 1968c. In: Rudé právo 48/245, 1.

Dienstbier, Jiří, 1998. Nebojme se svých vlastních dějinných činů. In: Mladá fronta DNES 9/195, 9. Filip, Ota. 1968c, To jste bratři? In: „III. společné zvláštní vydání (spojené deníky)“, 21. 8. 1968, 2.

Grišin, Aleksandr, 2018. Istorik Jevgenij Spicyn: Mify o Pražskoj vesne ispolzujut protiv nas po sej deň. In: Komsomolskaja pravda 2018/91, 9.

Hertl, David, 2018. Rok 1988: Dvacet let poté. „Rušivé akce v Praze“ k výročí srpnové invaze. In: Český rozhlas Plus. https://plus.rozhlas.cz/rok-1988-dvacet-let-pote-rusive-akce-vpraze-k-vyroci-srpnove-invaze-7591606.

Historické vítězství socialismu: Bratrské listy k událostem před deseti lety. 1978c. In: Rudé právo $58 / 198,7$.

Hlas o pokrytectví Západu. 1978d. In: Rudé právo 58/198, 7.

Indra, Alois, 1978a. Věrnost' intěrnacionalizmu. In: Izvěstija 1978/196, 5.

Indra, Alois, 1978b. Věrnost internacionalismu. In: Rudé právo 58/198, 6.

K rušivým akcím v Praze. 1988. In: Mladá fronta 44/199, 2.

Kobylkina, Irina, 1998. Čto auknulos` v 1968-m... K 30-letiju čechoslovackoj tragedii. In: Večerňaja Moskva 1998/184, 3.

Kondrašov, Aleksandr, 1998. Ob antičechoslovackoj kampanii na Zapadě. In: Izvěstija 1988/235, 1. Korrespondenty Pravdy i TASS. 1968. Věrnost' intěrnacionalnomu dolgu. In: Pravda 1968/236, 4.

Kosatík, Pavel, 2008. Katastrofa osmašedesátého roku ještě neskončila. In: Mladá fronta DNES 19/192, C1-C2.

Krivošejev, Vladlen, 1998. „Izvěstija“ i tanki v Prage. In: Izvěstija 1998/156, 4.

List Pravda k protičeskoslovenské kampani uměle rozdmýchávané na Západě. 1978b. In: Rudé právo 58/196, 2.

List Pravda o kampani imperialistické reakce: Chtějí ohrozit uvolňování. 1978. In: Mladá fronta 34/196, 1, 3. 
Luk'janov, Fjodor, 2018. Zastoj i gibkost'. In: Rossijskaja gazeta 2018/184, 6.

Martinek, Jan, 2018. Místo piety protest proti Babišovi. In: Právo 28/194, 1.

Násilná okupace ČSSR. 1968a. In: „IV. zvláštní vydání spojených deníkủ 21. srpna - 21 hod.“, 21. 8. 1968, 2.

Obrana socialismu i rozvoj socialismu - nedělitelný úkol strany a lidu. 1988a. In: Rudé právo $68 / 195,3$.

Opustte naši zemi. 1968b. In: „III. společné zvláštní vydání (spojené deníky)“, 21. 8. 1968, 2.

Pacner, Karel, 1998. Srpen 1968: stovka mrtvých, stovky zraněných, miliardové škody. In: Mladá fronta DNES 9/195, 3.

Parlament k normalizaci života. 1968a. In: Rudé právo 48/244, 1.

Pazderka, Josef, 2008. Sovětský generál a jeho pravda. In: Mladá fronta DNES 19/192, C12.

Pevná třídní pouta. 1978b. In: Rudé právo 58/198, 7.

Pozornost světového tisku postupu normalizace poměrů v ČSSR. 1968b. In: Rudé právo 48/249, 3.

Provokace nepřátel socialismu zmařena. 1988c. In: Rudé právo 68/197, 7.

Putna, Martin C., 1998. Sladká šedesátá a tanky jako dobrá výmluva. In: Mladá fronta DNES 9/194, 9.

Rušivé akce v Praze. 1988b. In: Rudé právo 68/197, 2.

Sněgirev, Vladimir a Fronin, Vladislav, 2018. Cena svobody. In: Rossijskaja gazeta 2018/183, 7.

Šikarev, Leonid, 1998. Vtorženije v Čechoslovakiju: 30 let spustja. Bez stracha pěred pravdoj. In: Izvěstija 1998/155, 1, 7.

Trajnin, A., 1988. Provokacija presečena. In: Večerňaja Moskva 1988/192, 3.

V zájmu pracujících: Sovětský list Pravda cituje z článku RP o 20. výročí poskytnutí internacionální pomoci. 1988c. In: Rudé právo 68/197, 7.

V zájmu socialismu, v zájmu našeho lidu. 1978a. In: Rudé právo 58/196, 1 - 2.

Vedrussov, Aleksandr, 2018. Vspomnit’ vsjo. In: Izvěstija 2018/154, 3.

Vo imja pobědy socializma. 1978. In: Pravda 1978/234, 4.

Zajavlenije TASS. 1968a. In: Pravda 1968/234, 1.

Zaščita socializma - vysšij intěrnacionalnyj dolg. 1968b. In: Pravda 1968/235, 2 - 3.

Zídek, Petr, 2018. Když prezident 21. srpna mlčí. In: Lidové noviny 31/194, 8.

\section{KONTAKT}

Mgr. Jaroslav Sommer

Katedra ruského jazyka a literatury

Pedagogická fakulta Univerzity Hradec Králové

Rokitanského 62

50003 Hradec Králové

Česká republika

jaroslav.sommer@uhk.cz

Vojtěch Jedlička

Katedra ruského jazyka a literatury

Pedagogická fakulta Univerzity Hradec Králové

Rokitanského 62

50003 Hradec Králové

Česká republika

vojtech.jedlicka@uhk.cz 